\title{
Alternative sources of potassium in coffee plants for better soil fertility, productivity, and beverage quality
}

\author{
Kaio Gonçalves de Lima Dias ${ }^{(1)}$, Paulo Tácito Gontijo Guimarães ${ }^{(2)}$, Davi Lopes do Carmo ${ }^{(3)}$, \\ Thiago Henrique Pereira Reis ${ }^{(4)}$ and Julian Junio de Jesus Lacerda ${ }^{(5)}$
}

\begin{abstract}
(1)Universidade Federal de Lavras, Departamento de Ciência do Solo, Caixa Postal 3037, CEP 37200-000 Lavras, MG, Brazil. E-mail: kaiogld@gmail.com (2)Empresa de Pesquisa Agropecuária de Minas Gerais, Centro Tecnológico do Sul de Minas, Campus da Universidade Federal de Lavras, Caixa Postal 176, CEP 37200-000 Lavras, MG, Brazil. E-mail: paulotgg@ufla.epamig.br (3)Universidade Federal de Viçosa, Departamento de Fitotecnia, Avenida P.H. Rolfs, s/no, Campus Universitário, CEP 36570-900 Viçosa, MG, Brazil. E-mail: davigoldan@yahoo.com.br (4)Yara Brasil Fertilizantes, BR-491, Km 176, s/no, Fazenda Nossa Senhora Aparecida, CEP $37130-000$ Alfenas, MG, Brazil. E-mail: thiagohpreis@yahoo.com.br (5)Universidade Federal do Piauí, Campus Professora Cinobelina Elvas, Rodovia Municipal Bom Jesus-Viana, Km 01, Planalto Horizonte, CEP 64900-000 Bom Jesus, PI, Brazil. E-mail: julianlacerda@gmail.com
\end{abstract}

Abstract - The objective of this work was to evaluate alternative sources of potassium for improving soil fertility and coffee productivity and beverage quality. The experiment was conducted in a coffee (Coffea arabica) crop, planted in an Oxisol area, in the municipality of Patrocínio, in the state of Minas Gerais, Brazil. The treatments consisted of the K sources TK47 and Super Greensand (SG) - both based on glauconite silicate mineral -, at the following doses: $0 \mathrm{~kg} \mathrm{ha}^{-1} \mathrm{~K}_{2} \mathrm{O}$ (control); 42, 84, 168, and $336 \mathrm{~kg} \mathrm{ha}^{-1} \mathrm{~K}_{2} \mathrm{O}$ from TK47; $618 \mathrm{~kg}$ $\mathrm{ha}^{-1} \mathrm{~K}_{2} \mathrm{O}$ from $\mathrm{KCl}$; and $168 \mathrm{~kg} \mathrm{ha}^{-1} \mathrm{~K}_{2} \mathrm{O}$ from SG. A randomized complete block design was used, with four replicates in each treatment. The experimental units consisted of three rows with ten plants each, using the eight central plants as the useful plot. Potassium fertilization with TK47 increased soil fertility, correcting soil acidity and elevating $\mathrm{K}^{+}, \mathrm{P}$, and $\mathrm{Ca}^{2+}$ contents, effective cation exchange capacity, and $\mathrm{Zn}^{2+}$ and $\mathrm{Fe}^{2+}$ levels in the soil. Fertilization with $336 \mathrm{~kg} \mathrm{ha}^{-1} \mathrm{~K}_{2} \mathrm{O}$ from TK47, in a single dose, provides grain yield and polyphenol oxidase activity similar to those of fertilization with $618 \mathrm{~kg} \mathrm{ha}^{-1} \mathrm{~K}_{2} \mathrm{O}$ from $\mathrm{KCl}$, in a split-dose, but a better sensory analysis of the resultant beverage.

Index terms: Coffea arabica, alternative fertilizers, coffee mineral nutrition, glauconite, potassium gradual solubilization, residual effect.

\section{Fontes alternativas de potássio em cafeeiros para melhoria da fertilidade do solo, da produtividade e da qualidade de bebida}

\begin{abstract}
Resumo - O objetivo deste trabalho foi avaliar fontes alternativas de potássio para melhoria da fertilidade do solo e da produtividade e da qualidade de bebida do cafeeiro. O experimento foi conduzido em lavoura de café (Coffea arabica) plantada em área de Latossolo, no Município de Patrocínio, no Estado de Minas Gerais. Os tratamentos consistiram da aplicação das fontes de K TK47 e Super Greensand (SG) - ambas baseadas no mineral silicatado glauconita -, nas seguintes doses: $0 \mathrm{~kg} \mathrm{ha}^{-1}$ de $\mathrm{K}_{2} \mathrm{O}$ (controle); 42, 84, 168 e $336 \mathrm{~kg} \mathrm{ha}^{-1} \mathrm{de}$ $\mathrm{K}_{2} \mathrm{O}$ de TK47; $618 \mathrm{~kg} \mathrm{ha}^{-1}$ de $\mathrm{K}_{2} \mathrm{O}$ de $\mathrm{KCl}$; e $168 \mathrm{~kg} \mathrm{ha}^{-1}$ de $\mathrm{K}_{2} \mathrm{O}$ de SG. Utilizou-se o delineamento de blocos ao acaso, com quatro repetições por tratamento. As unidades experimentais foram constituídas por três linhas de dez plantas cada uma, tendo-se considerado as oito plantas centrais como parcela útil. A adubação potássica com TK47 aumentou a fertilidade do solo, com correção da acidez e com elevação dos teores de $\mathrm{K}^{+}, \mathrm{P}, \mathrm{Ca}^{2+}$, da capacidade de troca de cátions efetiva, e dos níveis de $\mathrm{Zn}^{2+}$ e $\mathrm{Fe}^{2+}$ no solo. A adubação com $336 \mathrm{~kg} \mathrm{ha}^{-1}$ de $\mathrm{K}_{2} \mathrm{O}$ de TK47, em dose única, proporciona produção de grãos e atividade de polifenoloxidase semelhantes às da fertilização com $618 \mathrm{~kg} \mathrm{ha}^{-1}$ de $\mathrm{K}_{2} \mathrm{O}$ de $\mathrm{KCl}$, de forma parcelada, mas melhor análise sensorial da bebida resultante.
\end{abstract}

Termos para indexação: Coffea arabica, fertilizantes alternativos, nutrição mineral do cafeeiro, glauconita, solubilização gradual do potássio, efeito residual.

\section{Introduction}

Potassium is required and accumulated in large quantities by the coffee (Coffea spp.) plant, and the most common source for fertilization is potassium chloride. Potassium's relationship with coffee production is attributed to its participation in the enzyme activation of several metabolic processes in 
the plant, such as photosynthesis, synthesis of proteins and carbohydrates, and maintenance of cell turgidity (Malavolta, 2006; Ernani et al., 2007). The nutrient has been acknowledged as the "quality element" in plant nutrition, due to its role in metabolic processes and activation of enzymes that influence the chemical composition of coffee beans and, consequently, the quality of the resultant beverage (Guimarães et al., 2011). In contrast, the anion, $\mathrm{Cl}^{-}$, present in $\mathrm{KCl}$ reduces polyphenol oxidase activity, which is related to the quality of the beverage (Silva et al., 2002; Clemente et al., 2015). Therefore, it is essential to devise a $\mathrm{K}$ fertilizer that contributes maximally to crop productivity, without compromising any physiological features of the plant.

Brazil imports about $87 \%$ of its potassic fertilizers, mainly in the form of $\mathrm{KCl}$ (Sumário..., 2014). This low production creates a high dependence on the international market, while increasing production costs due to the high import rates and exchange variation. Therefore, there is a demand for alternative sources of $\mathrm{K}$ in order to reduce costs and dependence on the external market.

The alternative sources used as fertilizer in the present work are composed essentially of the glauconite silicate mineral with the molecular formula $\mathrm{K}_{2}(\mathrm{MgFe}) \cdot 2 \mathrm{Al}_{6} \cdot\left(\mathrm{Si}_{4} \mathrm{O}_{10}\right) \cdot 8(\mathrm{OH})_{12}$ (Dana, 1978). Super Greensand consists of $10 \% \mathrm{~K}_{2} \mathrm{O}, 1.8 \% \mathrm{Mg}, 27 \% \mathrm{Si}$, and $2.7 \% \mathrm{Fe}$; and TK47, of $7.0 \% \mathrm{~K}_{2} \mathrm{O}, 20 \% \mathrm{Ca}, 17 \% \mathrm{Si}$, $3.0 \% \mathrm{Mg}, 0.14 \% \mathrm{P}_{2} \mathrm{O}_{5}$, and $3.5 \% \mathrm{Fe}$. The latter source goes through a pyrometallurgical process for greater $\mathrm{K}$ solubilization.

Glauconite has been highlighted as an alternative source of $\mathrm{K}$, because it is relatively easy to explore its $\mathrm{K}_{2} \mathrm{O}$ contents, which range from 7 to $14 \%$ (Lima et al., 2007). Although it is a promising source of $\mathrm{K}$ for plants (Martins et al., 2015; Santos et al., 2015), further research is still needed regarding the coffee crop. Moreover, the solubility of potassic minerals present in the rock is low, requiring thermal and chemical processes with limestone addition to increase $\mathrm{K}$ solubilization, in order to overcome this obstacle (Silva et al., 2012; Martins et al., 2015).

The objective of this work was to evaluate alternative sources of potassium for improving soil fertility and coffee productivity and beverage quality.

\section{Materials and Methods}

The experiment was carried out in a dry coffee (Coffea arabica L.) crop of the IBC 12 cultivar, at the experimental farm of Empresa de Pesquisa Agropecuária de Minas Gerais (Epamig), located in the municipality of Patrocínio, in state of Minas Gerais, Brazil $\left(18^{\circ} 57^{\prime} \mathrm{S}, 47^{\circ} 00^{\prime} \mathrm{W}\right.$, at an average altitude of $930 \mathrm{~m}$ ). The climate of the experimental region is tropical, classified as of the Cwa type, according to Köppen, with a cold winter and a rainy summer. The average annual rainfall is $1,620 \mathrm{~mm}$ (Silva \& Malvino, 2005).

Before the installation of the experiment, soil samples were collected at the $0.00-0.20-\mathrm{m}$ depth, for chemical characterization. The soil was classified as a Latossolo Vermelho-Amarelo (Santos et al., 2013), i.e., a Typic Haplustox, with the following characteristics: $4.5 \mathrm{pH}$ in $\mathrm{H}_{2} \mathrm{O}, 42.5 \mathrm{mg} \mathrm{dm}^{-3} \mathrm{~K}^{+}, 8.2 \mathrm{mg} \mathrm{dm}{ }^{-3} \mathrm{P}, 7.0 \mathrm{mg} \mathrm{dm}^{-3}$ remaining phosphorus (P-rem), $1.8 \mathrm{cmol}_{\mathrm{c}} \mathrm{dm}^{-3} \mathrm{Ca}^{2+}$, $1.4 \mathrm{cmol}_{\mathrm{c}} \mathrm{dm}^{-3} \mathrm{Mg}^{2+}$, base saturation (BS) of $44.7 \%$, $0.4 \mathrm{cmol}_{\mathrm{c}} \mathrm{dm}^{-3} \mathrm{Al}^{+3}, 4.1 \mathrm{cmol}_{\mathrm{c}} \mathrm{dm}^{-3} \mathrm{H}+\mathrm{Al}$, aluminum saturation of $5.4 \%$, and $3.1 \mathrm{dag} \mathrm{kg}^{-1}$ organic matter.

Based on the soil chemical analysis, $1.4 \mathrm{Mg} \mathrm{ha}^{-1}$ calcitic limestone (total neutralizing power $=80 \%$ ) was applied three months before planting of the coffee seedlings, aiming at BS of $60 \%$. Limestone was applied and incorporated during soil tillage with plowing and harrowing, to a $0.00-0.20-\mathrm{m}$ depth. A total of $300 \mathrm{~g} \mathrm{~m}^{-1}$ simple superphosphate was applied in soil grooves. Soil correction, planting, and postplanting fertilizations during the experimental period were performed based on the soil analysis, according to fertilizer recommendations for the crop in the state of Minas Gerais (Guimarães et al., 1999), except for K.

The coffee seedlings were transplanted, spaced at 3.4x0.7 m, in December 2010. A randomized complete block design was used, with seven treatments and four replicates. Each experimental unit consisted of three rows of ten plants each, with the eight central ones being considered as the useful plot.

The treatments ( $\mathrm{T} 1$ to $\mathrm{T} 7$ ) consisted of the alternative K sources TK47 and Super Greensand (SG), both based on the glauconite silicate mineral, at the following doses: $\mathrm{T} 1,0 \mathrm{~kg} \mathrm{ha}^{-1} \mathrm{~K}_{2} \mathrm{O}$ (control); T2, T3, T4, and T5, respectively, 42, 84, 168, and $336 \mathrm{~kg} \mathrm{ha}^{-1} \mathrm{~K}_{2} \mathrm{O}$ from TK47; T6, $618 \mathrm{~kg} \mathrm{ha}^{-1} \mathrm{~K}_{2} \mathrm{O}$ from $\mathrm{KCl}$ (half at planting and half during the production phase, at 2.5 years); and $\mathrm{T} 7,168 \mathrm{~kg} \mathrm{ha}^{-1} \mathrm{~K}_{2} \mathrm{O}$ from SG. The recommended dose 
corresponded to $168 \mathrm{~kg} \mathrm{ha}^{-1} \mathrm{~K}_{2} \mathrm{O}$, according to the soil chemical analysis and to fertilizer recommendations for the crop in the state of Minas Gerais (Guimarães et al., 1999). TK47 and SG were applied in the planting pit. $\mathrm{KCl}$ was applied after planting, at the dose of 168 $\mathrm{kg} \mathrm{ha}^{-1} \mathrm{~K}_{2} \mathrm{O}$, split into three, at 20-day intervals.

After the first harvest, only the conventional source (KCl) was reapplied, in the amount of $450 \mathrm{~kg} \mathrm{ha}^{-1} \mathrm{~K}_{2} \mathrm{O}$, also divided into three, at 20-day intervals. This amount of $\mathrm{K}$ was used due to the high production expectation for the first harvest, 2.5 years after planting, considering the high $\mathrm{K}$ drainage in this stage (Guimarães et al., 1999). The alternative sources of $\mathrm{K}$ from glauconite were not reapplied in order to evaluate their residual effects. SG has about $10 \%$ total $\mathrm{K}_{2} \mathrm{O}, 1.8 \% \mathrm{Mg}, 27 \%$ total $\mathrm{Si}$, and $2.7 \% \mathrm{Fe}$; while TK47, which goes through the pyrometallurgical proprietary process to enhance $\mathrm{K}$ solubility, has about $7 \%$ total $\mathrm{K}_{2} \mathrm{O}, 20 \% \mathrm{Ca}, 17 \%$ total $\mathrm{Si}, 3.0 \% \mathrm{Mg}, 0.14 \% \mathrm{P}_{2} \mathrm{O}_{5}$, and $3.5 \% \mathrm{Fe}$.

In December 2012, soil samples were collected at the $0.00-0.20-\mathrm{m}$ depth, where fertilization was performed, for chemical characterization (Silva, 2009). The analyzes were carried out at the laboratory of soils and plant nutrition of Epamig, in the municipality of Lavras, also in the state of Minas Gerais.

To evaluate the nutritional status of the plants, 50 pairs of leaves (third or fourth pairs counted from the tip of the branch) were collected from plants within the useful area, at the beginning of January 2013. Coffee bean samples were then collected, washed, placed in paper bags, and dried in an oven until they reached constant weight (Malavolta et al., 1997).

Grain production was evaluated in June 2013, in the useful plots. A total of $5 \mathrm{~L}$ cherry coffee per plot were collected, and then pulped and dried separately in individual suspended sieves. After drying and benefiting, samples were coded and sent for the quality analysis of the beverage. The sensorial analysis of coffee was carried out by three specialist tasters of Brazil Specialty Coffee Association at Cooperativa Regional de Cafeicultores em Guaxupé Ltda., located in the municipality of Guaxupé, in the state of Minas Gerais. The enzymatic activity of polyphenol oxidase was determined according to Ponting \& Joslyng (1948), using the sample extract without L-3,4dihydroxyphenylalanine (L-DOPA).

Data were subjected to the analysis of variance, and means were compared by the Scott-Knott test, at 5\% probability, using the Sisvar statistical software (Ferreira, 2014).

\section{Results and Discussion}

The dose of $336 \mathrm{~kg} \mathrm{ha}^{-1} \mathrm{~K}_{2} \mathrm{O}$ from TK47, applied in treatment $\mathrm{T} 5$, promoted a significant elevation in $\mathrm{pH}$, $\mathrm{BS}, \mathrm{P}-\mathrm{rem}$, and $\mathrm{P}, \mathrm{K}^{+}, \mathrm{Ca}^{2+}$, effective cation exchange capacity (ECEC), $\mathrm{Zn}^{2+}$, and $\mathrm{Fe}^{2+}$ levels, compared with the control and the other treatments (Table 1). Soil pH was 6.33 in T5, within the ideal range for the coffee crop (Guimarães et al., 1999); however, in the other treatments, $\mathrm{pH}$ values were between 4.2 and 5.2, below the ideal.

The ability of TK47 to correct soil acidity is due to the presence of silicate and carbonate anions. Ions including $\mathrm{Ca}^{2+}$ and $\mathrm{K}^{+}$displace $\mathrm{Al}^{3+}$ from the exchange complex, while $\mathrm{SiO}_{3}$ neutralizes the $\mathrm{H}^{+}$ions in the soil solution and converts them to $\mathrm{H}_{2} \mathrm{SiO}_{3}$ (Sarto et al., 2014). Due to the tendency of silicate to neutralize acidic components, mainly as $\mathrm{Ca}^{2+}$ and $\mathrm{K}^{+}$ions, TK47 also promotes an increase in BS. This corrective effect

Table 1. Soil chemical analysis as a function of fertilization with different K sources and doses ${ }^{(1)}$.

\begin{tabular}{|c|c|c|c|c|c|c|c|c|c|c|c|c|c|}
\hline \multirow[t]{2}{*}{ Treatment $^{(2)}$} & \multirow{2}{*}{$\begin{array}{c}\mathrm{pH} \\
\left(\mathrm{H}_{2} \mathrm{O}\right)\end{array}$} & \multirow{2}{*}{$\begin{array}{l}\text { P-rem } \\
\left(\mathrm{g} \mathrm{L}^{-1}\right)\end{array}$} & $\mathrm{P}$ & $\mathrm{K}^{+}$ & $\mathrm{Ca}^{2+}$ & $\mathrm{Mg}^{2+}$ & ECEC & \multirow{2}{*}{$\begin{array}{l}\text { BS } \\
(\%)\end{array}$} & $\mathrm{Zn}^{2+}$ & $\mathrm{Cu}^{2+}$ & $\mathrm{Fe}^{2+}$ & $\mathrm{Mn}^{2+}$ & B \\
\hline & & & \multicolumn{2}{|c|}{$---\left(\mathrm{mg} \mathrm{dm}^{-3}\right)--$} & \multicolumn{3}{|c|}{ 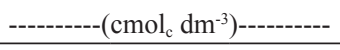 } & & -------- & 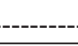 & $\mathrm{mg} \mathrm{dm}^{-}$ & & -------- \\
\hline T1 & $4.5 b$ & $9.7 \mathrm{c}$ & $10.6 b$ & $44.6 \mathrm{c}$ & $1.8 \mathrm{c}$ & $1.5 \mathrm{a}$ & $3.8 \mathrm{c}$ & $47 \mathrm{c}$ & $5.1 \mathrm{~b}$ & $11.7 \mathrm{a}$ & $34.5 \mathrm{c}$ & $12.8 \mathrm{a}$ & $1.15 \mathrm{a}$ \\
\hline $\mathrm{T} 2$ & $4.4 b$ & $9.9 \mathrm{c}$ & $17.8 \mathrm{~b}$ & $92.3 \mathrm{c}$ & $1.8 \mathrm{c}$ & $1.0 \mathrm{a}$ & $3.9 \mathrm{c}$ & $35 d$ & $5.2 b$ & $7.30 \mathrm{a}$ & $38.3 \mathrm{c}$ & $14.8 \mathrm{a}$ & $1.16 \mathrm{a}$ \\
\hline $\mathrm{T} 3$ & $4.7 b$ & $9.6 \mathrm{c}$ & $11.5 b$ & $186 b$ & $2.5 \mathrm{c}$ & $1.3 \mathrm{a}$ & $4.7 \mathrm{c}$ & $51 \mathrm{c}$ & $4.7 b$ & $12.2 \mathrm{a}$ & $40.4 \mathrm{c}$ & $13.6 \mathrm{a}$ & $1.18 \mathrm{a}$ \\
\hline $\mathrm{T} 4$ & $5.2 b$ & $11.6 \mathrm{~b}$ & $19.2 b$ & $226 b$ & $4.0 \mathrm{~b}$ & $1.2 \mathrm{a}$ & $5.9 \mathrm{~b}$ & $65 b$ & $8.0 \mathrm{~b}$ & $10.7 \mathrm{a}$ & $66.9 \mathrm{~b}$ & $19.7 \mathrm{a}$ & $1.41 \mathrm{a}$ \\
\hline T5 & $6.3 \mathrm{a}$ & $13.5 \mathrm{a}$ & $89.7 \mathrm{a}$ & $875 a$ & $8.4 \mathrm{a}$ & $1.1 \mathrm{a}$ & $11.8 \mathrm{a}$ & $89 a$ & $12.1 \mathrm{a}$ & $9.80 \mathrm{a}$ & $98.8 \mathrm{a}$ & $18.7 \mathrm{a}$ & $1.28 \mathrm{a}$ \\
\hline T6 & $4.5 b$ & $10.9 b$ & $13.5 b$ & $114 b$ & $2.0 \mathrm{c}$ & $1.3 \mathrm{a}$ & $3.9 \mathrm{c}$ & $46 c$ & $4.2 \mathrm{~b}$ & $8.10 \mathrm{a}$ & $36.8 \mathrm{c}$ & $14.1 \mathrm{a}$ & $1.09 \mathrm{a}$ \\
\hline $\mathrm{T} 7$ & $4.2 \mathrm{~b}$ & $10.9 b$ & $18.6 b$ & $70.3 \mathrm{c}$ & $2.4 \mathrm{c}$ & $1.3 \mathrm{a}$ & $4.3 \mathrm{c}$ & $44 c$ & $6.4 b$ & $14.5 \mathrm{a}$ & $37.6 \mathrm{c}$ & $15.4 \mathrm{a}$ & $1.11 \mathrm{a}$ \\
\hline
\end{tabular}

${ }^{(1)}$ Means followed by equal letters, in the columns, do not differ significantly by the Scott-Knott test, at $5 \%$ probability. ${ }^{(2)} \mathrm{T}, 0 \mathrm{~kg}$ ha- $\mathrm{K}_{2} \mathrm{O}$ (control); $\mathrm{T} 2$, $\mathrm{T} 3$, T4, and T5, 42, 84, 168, and $336 \mathrm{~kg} \mathrm{ha}^{-1} \mathrm{~K}_{2} \mathrm{O}$ from TK47, respectively; T6, $618 \mathrm{~kg} \mathrm{ha}^{-1} \mathrm{~K}_{2} \mathrm{O}$ from KCl; and T7, $168 \mathrm{~kg} \mathrm{ha}^{-1} \mathrm{~K}_{2} \mathrm{O}$ from Super Greensand. ECEC, effective cation exchange capacity; and BS, base saturation. 
in acidity with the application of silica rocks was also observed in works by von Wilpert \& Lukes (2003), using phonolite, and by Moreira et al. (2006), with volcanic sandstone rocks.

The greater $\mathrm{P}$ availability in the soil of treatment T5 was mainly caused by the increase in $\mathrm{pH}$ (Sandim et al., 2014), due to the desorption and saturation of $P$ adsorption sites by Si when TK47 was used (Carvalho et al., 2000; Pozza et al., 2007; Sandim et al., 2014). Pulz et al. (2008) observed an increased desorption and uptake of P by the potato (Solanum tuberosum L.) crop, when subjected to excessive use of calcium and magnesium silicate.

Treatment T5 also showed a significant increase in $\mathrm{K}^{+}$content in the soil, which reached $875 \mathrm{mg} \mathrm{dm}^{-3}$, whereas in T6, with the dose of $618 \mathrm{~kg} \mathrm{ha}^{-1} \mathrm{~K}_{2} \mathrm{O}$ from $\mathrm{KCl}$, the obtained value was $114 \mathrm{mg} \mathrm{dm}^{-3}$. This was attributed to the more gradual release of nutrients with TK47 use, due to its lower solubility, which reduces losses by leaching and increases residual effect (Melamed et al., 2009).

Duarte et al. (2013) reported higher $\mathrm{K}^{+}$leaching when $\mathrm{KCl}$ was used, compared with thermopotash. In the present study, when comparing the equivalent doses of $168 \mathrm{~kg} \mathrm{ha}^{-1} \mathrm{~K}_{2} \mathrm{O}$, from TK47 and SG, applied in $\mathrm{T} 4$ and T7, respectively, it was observed that the former provided $\mathrm{K}^{+}$contents in the topsoil more than three times greater than that of the latter. This result confirms the efficiency of TK47 in enhancing $\mathrm{K}^{+}$ solubilization due to the pyrometallurgical process it undergoes. Calcination, grinding, melting with other materials, and acid solubilization are commonly used to solubilize rocks; these techniques are based on physicochemical principles and alter the crystalline structure of minerals, increasing the release of $\mathrm{K}^{+}$ (Silva et al., 2012).

The dose of $336 \mathrm{~kg} \mathrm{ha}^{-1} \mathrm{~K}_{2} \mathrm{O}$ used in treatment $\mathrm{T} 5$ added about $991 \mathrm{~kg} \mathrm{ha}^{-1} \mathrm{Ca}$ to the soil, justifying the highest $\mathrm{Ca}^{2+}$ contents observed with this treatment. However, the contents of $\mathrm{Mg}^{2+}$ in the soil were, in general, similar between treatments and above the level of $0.8 \mathrm{cmol}_{\mathrm{c}} \mathrm{dm}^{3}$ considered critical for coffee (Guimarães et al., 1999). It should be pointed out that, even with the elevation of $\mathrm{pH}$, T5 still provided the highest levels of $\mathrm{Zn}^{2+}$ and $\mathrm{Fe}^{2+}$, which is justified by the presence of these elements in glauconite (Toledo Piza et al., 2011; Santos et al., 2015).

It is important to note that the results of the soil chemical analysis were obtained after two years of providing nutrients to the coffee tree, through the treatments, since the beginning of the crop, which was harvested after six months of this evaluation. These results show that TK47, due to its more gradual solubility, was able to raise $\mathrm{pH}, \mathrm{BS}, \mathrm{P}-\mathrm{rem}$, and $\mathrm{P}, \mathrm{K}^{+}$, $\mathrm{Ca}^{2+}, \mathrm{ECEC}, \mathrm{Zn}^{2+}$, and $\mathrm{Fe}^{2+}$ levels even after the coffee crop absorbed nutrients during both years.

The treatments resulted in significant differences in the leaf contents of $\mathrm{N}, \mathrm{K}, \mathrm{Ca}, \mathrm{Mg}, \mathrm{Cu}, \mathrm{Mn}$, and $\mathrm{Zn}$, whereas those of $\mathrm{P}, \mathrm{B}$, and Fe did not differ (Table 2).

Nitrogen contents were higher for T3, but lower for T5. Treatment T6, with the conventional source $\mathrm{KCl}$, provided the highest foliar content of $\mathrm{K}$, followed by T5 using TK47, which presented higher $\mathrm{K}$ contents than the control and the other treatments. Although T5 provided the highest availability of $\mathrm{K}$ in the soil, it had the highest harvest forecast, indicating that there was a $\mathrm{K}$ drain for the coffee fruits. T6 was the only treatment that received cover fertilization in the second year after planting, which justifies the obtained result.

Table 2. Foliar nutrient contents in coffee (Coffea arabica) subjected to fertilization with different K sources and doses ${ }^{(1)}$.

\begin{tabular}{|c|c|c|c|c|c|c|c|c|c|c|}
\hline \multirow[t]{2}{*}{ Treatment $^{(2)}$} & $\mathrm{N}$ & $\mathrm{P}$ & $\mathrm{K}$ & $\mathrm{Ca}$ & $\mathrm{Mg}$ & $\mathrm{Cu}$ & $\mathrm{B}$ & $\mathrm{Fe}$ & $\mathrm{Mn}$ & $\mathrm{Zn}$ \\
\hline & \multicolumn{5}{|c|}{ 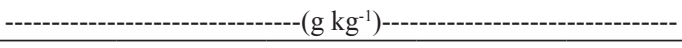 } & \multicolumn{5}{|c|}{ 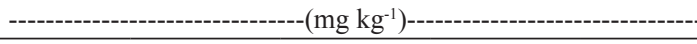 } \\
\hline $\mathrm{T} 1$ & $33 \mathrm{c}$ & $1.4 \mathrm{a}$ & $10 \mathrm{c}$ & $17 \mathrm{a}$ & $8.4 \mathrm{a}$ & $15 b$ & $104 \mathrm{a}$ & $97 \mathrm{a}$ & $218 b$ & $12 \mathrm{c}$ \\
\hline $\mathrm{T} 2$ & $36 b$ & $1.4 \mathrm{a}$ & $10 \mathrm{c}$ & $15 b$ & $7.1 \mathrm{~b}$ & $16 b$ & $107 \mathrm{a}$ & $91 \mathrm{a}$ & $250 \mathrm{~b}$ & $12 \mathrm{c}$ \\
\hline $\mathrm{T} 3$ & $39 a$ & $1.3 \mathrm{a}$ & $10 \mathrm{c}$ & $15 b$ & $6.9 \mathrm{~b}$ & $17 b$ & $102 \mathrm{a}$ & $102 \mathrm{a}$ & $249 b$ & $23 a$ \\
\hline $\mathrm{T} 4$ & $36 b$ & $1.2 \mathrm{a}$ & $11 \mathrm{c}$ & $15 \mathrm{~b}$ & $6.3 \mathrm{c}$ & $16 \mathrm{~b}$ & $97 \mathrm{a}$ & $95 \mathrm{a}$ & $246 b$ & $15 b$ \\
\hline T5 & $31 d$ & $1.3 \mathrm{a}$ & $12 b$ & $16 \mathrm{a}$ & $6.5 \mathrm{c}$ & $14 b$ & $104 \mathrm{a}$ & $101 \mathrm{a}$ & $217 \mathrm{~b}$ & $14 b$ \\
\hline T6 & $35 b$ & $1.2 \mathrm{a}$ & $15 \mathrm{a}$ & $14 b$ & $4.1 \mathrm{~d}$ & $22 \mathrm{a}$ & $102 a$ & $102 \mathrm{a}$ & $380 \mathrm{a}$ & $13 \mathrm{c}$ \\
\hline $\mathrm{T} 7$ & $35 \mathrm{~b}$ & $1.2 \mathrm{a}$ & $11 \mathrm{c}$ & $14 \mathrm{~b}$ & $6.2 \mathrm{c}$ & $21 \mathrm{a}$ & $106 \mathrm{a}$ & $100 \mathrm{a}$ & $314 \mathrm{a}$ & $14 b$ \\
\hline
\end{tabular}

${ }^{(1)}$ Means followed by equal letters, in the columns, do not differ significantly by the Scott-Knott test, at $5 \%$ probability. ${ }^{(2)} \mathrm{T} 1,0 \mathrm{~kg}$ ha ${ }^{-1} \mathrm{~K}_{2} \mathrm{O}$ (control); $\mathrm{T} 2, \mathrm{~T} 3, \mathrm{~T} 4$, and T5, 42, 84, 168, and $336 \mathrm{~kg} \mathrm{ha}^{-1} \mathrm{~K}_{2} \mathrm{O}$ from TK47, respectively; T6, $618 \mathrm{~kg} \mathrm{ha}^{-1} \mathrm{~K}_{2} \mathrm{O}$ from KCl; and T7, $168 \mathrm{~kg}$ ha-1 $\mathrm{K}_{2} \mathrm{O}$ from Super Greensand. 
Foliar Ca content was higher in the control (T1) and in the treatment with a higher dose of TK47 (T5). Two factors may have contributed to these results: the low fruit load in the plants in T1; and the high availability of $\mathrm{Ca}^{2+}$ in the soil in $\mathrm{T} 5$.

The treatments with potassic fertilizations showed lower Mg leaf contents, compared with the control (T1). This could be explained by the competitive inhibition in the absorption of this nutrient due to the presence of $\mathrm{K}$ and $\mathrm{Ca}$ (Ding et al., 2006), since the contents of $\mathrm{Mg}^{2+}$ in the soil did not differ. The contents of $\mathrm{Cu}$ and $\mathrm{Mn}$ in the leaves showed a similar behavior, being higher in $\mathrm{T} 6$ and $\mathrm{T} 7$, in comparison with the control and the other treatments. The content of $\mathrm{Zn}\left(23 \mathrm{mg} \mathrm{kg}^{-1}\right)$ was higher in T3, ranging from 12 to $15 \mathrm{mg} \mathrm{kg}^{-1}$ in the other treatments. The main factors that caused the changes observed in macro- and micronutrient levels in the leaf analysis are production load, soil $\mathrm{pH}$, soil nutrient balance, type of $\mathrm{K}$ source, and doses of $\mathrm{K}_{2} \mathrm{O}$ applied in the treatments.

Treatments T5 and T6 had similar and significantly higher productivity, compared with the control and the other treatments (Figure 1). This result is explained by the higher doses of $\mathrm{K}_{2} \mathrm{O}$ used. The amount of $\mathrm{K}_{2} \mathrm{O}$ in

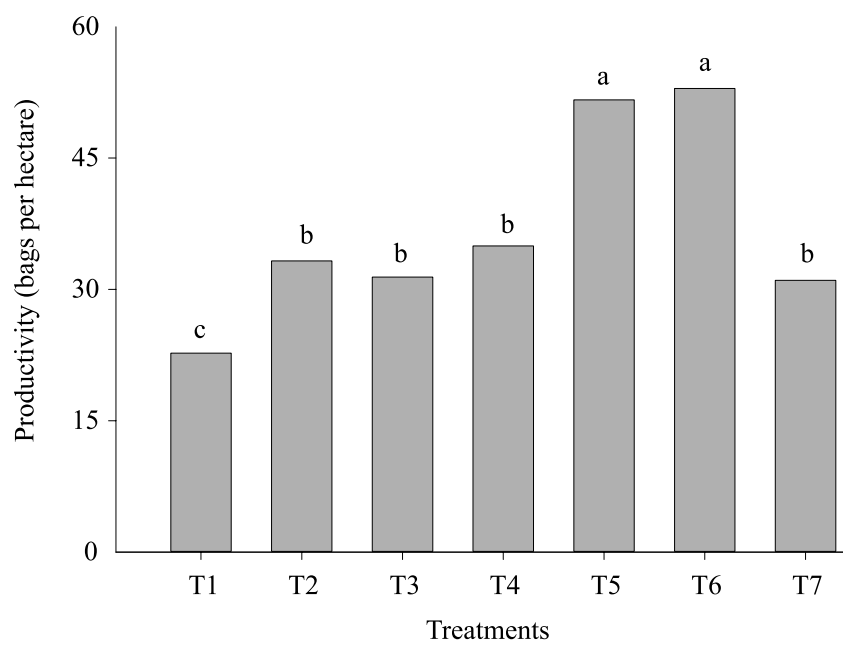

Figure 1. Productivity of coffee (Coffea arabica) plants subjected to fertilization with different $\mathrm{K}$ sources and doses. Means followed by equal letters, in the columns, do not differ significantly by the Scott-Knott test, at $5 \%$ probability. T1, $0 \mathrm{~kg} \mathrm{ha}^{-1} \mathrm{~K}_{2} \mathrm{O}$ (control); T2, T3, T4, and T5, 42, 84, 168, and $336 \mathrm{~kg} \mathrm{ha}^{-1} \mathrm{~K}_{2} \mathrm{O}$ from TK47, respectively; $\mathrm{T} 6,618 \mathrm{~kg} \mathrm{ha}^{-1} \mathrm{~K}_{2} \mathrm{O}$ from $\mathrm{KCl}$; and $\mathrm{T} 7,168 \mathrm{~kg} \mathrm{ha}^{-1} \mathrm{~K}_{2} \mathrm{O}$ from Super Greensand.
T6 was established as a function of the high production expectation, common for the first harvest. In this case, production fertilizations are recommended as $\mathrm{K}$ drainage in the fruits is high (Guimarães et al., 1999).

TK47 was able to supply the coffee crop with K more gradually than $\mathrm{KCl}$, since the application of approximately $54 \% \mathrm{~K}_{2} \mathrm{O}$ in $\mathrm{T} 5$ resulted in productivities similar to those of T6. It was verified that the SG source also has potential to supply $\mathrm{K}$ to plants, considering productivity was superior to that of the control and statistically similar to that of the TK47 source at 186 $\mathrm{kg} \mathrm{ha}^{-1} \mathrm{~K}_{2} \mathrm{O}$.

The addition of crushed rocks to the soil, especially of mafic ones, has shown good results for some crops (Silverol \& Machado Filho, 2007; Silva et al., 2008; Prates et al., 2015). According to Theodoro \& Leonardos (2006), rock application allowed corn (Zea mays L.), rice (Oryza sativa L.), cassava (Manihot esculenta Crantz), sugarcane (Saccharum officinarum L.), and similar crops to be maintained at conventional fertilization levels. However, a lack of yield responses has also been observed in some works, which may be associated to: the short cycle of the crops used as test plants, short evaluation periods, unfavorable climatic conditions, use of sterile soils with low microbial activity, or the agromineral used as a nutrient source (Silva et al., 2008; Prates et al., 2012).

The quality of the coffee beverage and polyphenol oxidase activity were significantly affected by the

Table 3. Quality of the coffee (Coffea arabica) beverage as a function of fertilization with different $\mathrm{K}$ sources and $\operatorname{doses}^{(1)}$.

\begin{tabular}{lcc}
\hline Treatment $^{(2)}$ & $\begin{array}{c}\text { Sensory analysis } \\
\text { Score }\end{array}$ & $\begin{array}{c}\text { PPO activity } \\
\left(\mathrm{U} \mathrm{min}^{-1} \mathrm{~g}^{-1}\right)\end{array}$ \\
\hline T1 & $73 \mathrm{~b}$ & $41 \mathrm{~d}$ \\
$\mathrm{~T} 2$ & $64 \mathrm{c}$ & $43 \mathrm{c}$ \\
$\mathrm{T} 3$ & $69 \mathrm{~b}$ & $44 \mathrm{~b}$ \\
$\mathrm{~T} 4$ & $71 \mathrm{~b}$ & $46 \mathrm{a}$ \\
$\mathrm{T} 5$ & $84 \mathrm{a}$ & $45 \mathrm{a}$ \\
$\mathrm{T} 6$ & $70 \mathrm{~b}$ & $43 \mathrm{c}$ \\
$\mathrm{T} 7$ & $71 \mathrm{~b}$ & $44 \mathrm{~b}$ \\
\hline
\end{tabular}

${ }^{(1)}$ Means followed by equal letters, in the columns, do not differ significantly by the Scott-Knott test, at $5 \%$ probability. ${ }^{(2)} \mathrm{T} 1,0 \mathrm{~kg} \mathrm{ha}^{-1} \mathrm{~K}_{2} \mathrm{O}$ (control); T2, T3, T4, and T5, 42, 84, 168, and $336 \mathrm{~kg} \mathrm{ha}^{-1} \mathrm{~K}_{2} \mathrm{O}$ from TK47, respectively; T6, $618 \mathrm{~kg} \mathrm{ha}^{-1} \mathrm{~K}_{2} \mathrm{O}$ from $\mathrm{KCl}$; and T7, $168 \mathrm{~kg} \mathrm{ha}^{-1} \mathrm{~K}_{2} \mathrm{O}$ from Super Greensand. PPO, polyphenol oxidase.

Pesq. agropec. bras., Brasília, v.53, n.12, p.1355-1362, Dec. 2018 DOI: $10.1590 / \mathrm{S} 0100-204 \mathrm{X} 2018001200008$ 
$\mathrm{K}$ sources and doses (Table 3). The source TK47, with the highest dose of $\mathrm{K}_{2} \mathrm{O}$ in $\mathrm{T} 5$, showed the best score for the sensorial analysis, indicating that the quality of the resultant beverage was superior to that of the other treatments. This result is justified by the greater soil availability of $\mathrm{K}$ in $\mathrm{T} 5$, together with the absence of $\mathrm{Cl}^{-}$in the applied source, i.e., TK47. As previously highlighted, $\mathrm{K}$ is considered to be the nutrient of quality due to its influence on the chemical composition of coffee beans (Guimarães et al., 2011). According to Martinez et al. (2014), in K-deficient plants, the accumulation of soluble carbohydrates, the decrease in starch content, the accumulation of soluble $\mathrm{N}$ compounds, and the changes observed in the plant metabolism are related to the high $\mathrm{K}$ requirement for the functioning of regulatory enzymes, mainly pyruvate kinase and phosphofructokinase (Martinez et al., 2014). In addition to acting on the carbohydrate metabolism, which affects beverage quality, severe $\mathrm{K}$ deficiency in plant tissues leads to the synthesis of toxic amines, such as putrescine and agmatine, which are dreadfully harmful to the quality of the drink (Guimarães et al., 2011). Some authors attribute a decrease in the quality of the beverage to the $\mathrm{Cl}^{-}$anion, which comes with the application of $\mathrm{KCl}$ (Carvalho et al., 1994; Silva et al., 2002).

Polyphenol oxidase activity was higher in T4 and $\mathrm{T} 5$ - which received 168 and $336 \mathrm{~kg} \mathrm{ha}^{-1} \mathrm{~K}_{2} \mathrm{O}$ from TK47, respectively -, compared with the other treatments. According to Martinez et al. (2014), polyphenol oxidase is a cupric enzyme linked to cell membranes. In adverse conditions or when the fruit cells are damaged, polyphenol oxidase acts on intra- and extracellular polyphenols, promoting the hydroxylation of monophenols to o-diphenols, which undergo $\mathrm{H}^{+}$removal and give rise to o-quinones that inhibit polyphenol oxidase. Therefore, the polyphenol oxidase activity, which is strongly influenced by the metabolism of phenols, correlates significantly with the quality of the beverage, decreasing from the best to the worst quality.

However, these results did not corroborate those of Carvalho et al. (1994), who related polyphenol oxidase activity to different classes of drink: "riado" and "rio", $<55.99 \mathrm{U} \mathrm{m}^{-1} \mathrm{~g}^{-1}$; "hard", 55.99 to $62.99 \mathrm{U} \mathrm{m}^{-1} \mathrm{~g}^{-1}$; "soft", 62.99 to $67.66 \mathrm{U} \mathrm{m}^{-1} \mathrm{~g}^{-1}$; and "strictly soft", $>67.66 \mathrm{U}$ $\mathrm{m}^{-1} \mathrm{~g}^{-1}$. In the present study, the polyphenol oxidase activity for T5 was $45 \mathrm{U} \mathrm{m}^{-1} \mathrm{~g}^{-1}$, which, according to those authors, would be classified as "riado" or "rio"; however, the sample received 84 points in the sensorial analysis, which corresponds to a soft drink, as described by Dalvi (2011).

In view of the overall results, the regional use of TK47 is a good alternative source for supplying $\mathrm{K}$ and other nutrients in the initial phase of coffee production. However, there is a need for more studies on different crops and soils, with longer periods of evaluation, in order to verify the behavior of the tested sources and doses.

\section{Conclusions}

1. Potassium fertilization with TK47 increases soil fertility, corrects soil acidity, and elevates $\mathrm{K}^{+}, \mathrm{P}, \mathrm{Ca}^{2+}$, effective cation exchange capacity, $\mathrm{Zn}^{2+}$, and $\mathrm{Fe}^{2+}$ contents in the soil.

2. Fertilization with $336 \mathrm{~kg} \mathrm{ha}^{-1} \mathrm{~K}_{2} \mathrm{O}$ from TK47, in a single dose, provides coffee (Coffea arabica) grain yield and polyphenol oxidase activity similar to those of fertilization with $618 \mathrm{~kg} \mathrm{ha}^{-1} \mathrm{~K}_{2} \mathrm{O}$ from $\mathrm{KCl}$, in a split dose, but a better sensory analysis of the resultant beverage.

\section{Acknowledgments}

To Consórcio Pesquisa Café, for scholarship granted and to Verde Agritech, for financial support.

\section{References}

CARVALHO, R.; FURTINI NETO, A.E.; CURI, N.; FERNANDES, L.A.; OLIVEIRA JR., A.C. Dessorção de fósforo por silício em solos cultivados com eucalipto. Revista Brasileira de Ciência do Solo, v.24, p.69-74, 2000. DOI: 10.1590/S010006832000000100009 .

CARVALHO, V.D. de; CHAGAS, S.J. de R.; CHALFOUN, S.M.; BOTREL, N.; JUSTE JUNIOR, E.S.G. Relação entre a composição físico-química e química do grão beneficiado e a qualidade de bebida do café. I - Atividades de polifenoloxidase e peroxidase, índice de coloração de acidez. Pesquisa Agropecuária Brasileira, v.29, p.449-454, 1994.

CLEMENTE, J.M.; MARTINEZ, H.E.P.; ALVES, L.C.; FINGER, F.L.; CECON, P.R. Effects of nitrogen and potassium on the chemical composition of coffee beans and on beverage quality. Acta Scientiarum. Agronomy, v.37, p.297-305, 2015. DOI: 10.4025/actasciagron.v37i3.19063.

DALVI, L.P. Qualidade dos cafés verde-cana e cereja preparados por via úmida. 2011. 58p. Tese (Doutorado) Universidade Federal de Viçosa, Viçosa. 
DANA, J.D. Silicatos. In: DANA, J.D.; HURLBULT, C.S. Manual de Mineralogia. Rio de Janeiro: Livros Técnicos e Científicos, 1978. v.2, p.423-564.

DING, Y.; LUO, W.; XU, G. Characterisation of magnesium nutrition and interaction of magnesium and potassium in rice. Annals of Applied Biology, v.149, p.111-123, 2006. DOI: 10.1111/ j.1744-7348.2006.00080.x.

DUARTE, I.N.; PEREIRA, H.S.; KORNDÖRFER, G.H. Lixiviação de potássio proveniente do termopotássio. Pesquisa Agropecuária Tropical, v.43, p.195-200, 2013. DOI: 10.1590/ S1983-40632013000200003.

ERNANI, P.R.; ALMEIDA, J.A. de; SANTOS, F.C. dos. Potássio. In: NOVAIS, R.F.; ALVAREZ V., V.H.; BARROS, N.F. de; FONTES, R.L.F.; CANTARUTTI, R.B.; NEVES, J.C.L. (Ed.). Fertilidade do solo. Viçosa: Sociedade Brasileira de Ciência do Solo, 2007. v.1, p.551-594.

FERREIRA, D.F. Sisvar: a guide for its bootstrap procedures in multiple comparisons. Ciência e Agrotecnologia, v.38, p.109112, 2014. DOI: 10.1590/S1413-70542014000200001.

GUIMARÃES, P.T.G.; GARCIA, A.W.R.; ALVAREZ V., V.H.; PREZOTTI, L.C.; VIANA, A.S.; MIGUEL, A.E.; MALAVOLTA, E.; CORREAA, J.B.; LOPES, A.S.; NOGUEIRA, F.D.; MONTEIRO, A.V.C. Cafeeiro. In: RIBEIRO, A.C.; GUIMARÃES, P.T.G.; ALVAREZ V., V.H. (Ed.). Recomendações para o uso de corretivos e fertilizantes em Minas Gerais: 5a aproximação. Viçosa: Comissão de Fertilidade do Solo do Estado de Minas Gerais, 1999. p.217-218.

GUIMARÃES, P.T.G.; NOGUEIRA, F.D.; MALTA, M.T.; DIAS, K.G. de L.; REIS, T.H.P. Nutrição do cafeeiro e sua relação com a qualidade do café. Informe Agropecuário, v.32, p.39-51, 2011.

LIMA, O.N.B.; UHLEIN, A.; BRITTO, W. de. Estratigrafia do Grupo Bambuí na Serra da Saudade e geologia do depósito fosfático de cedro do Abaeté, Minas Gerais. Revista Brasileira de Geociências, v.37, p.204-215, 2007. Suplemento.

MALAVOLTA, E. Manual de nutrição mineral de plantas. São Paulo: Agronômica Ceres, 2006. 638p.

MALAVOLTA, E.; VITTI, G.C.; OLIVEIRA, S.A. de. Avaliação do estado nutricional das plantas: princípios e aplicações. 2.ed. Piracicaba: Associação Brasileira para Pesquisa da Potassa e do Fosfato, 1997. 319p.

MARTINEZ, H.E.P.; CLEMENTE, J.M.; LACERDA, J.S. de; NEVES, Y.P.; PEDROSA, A.W. Nutrição mineral do cafeeiro e qualidade da bebida. Revista Ceres, v.61, p.838-848, 2014. Suplemento. DOI: 10.1590/0034-737X201461000009.

MARTINS, V.; GONÇALVES, A.S.F.; MARCHI, G.; GUILHERME, L.R.G.; MARTINS, É. de S. Solubilização de potássio em misturas de verdete e calcário tratadas termoquimicamente. Pesquisa Agropecuária Tropical, v.45, p.66-72, 2015.

MELAMED, R.; GASPAR, J.C.; MIEKELEY, N. Pó-derocha como fertilizante alternativo para sistemas de produção sustentáveis em solos tropicais. In: LAPIDO-LOUREIRO, F.E.; MELAMED, R.; FIGUEIREDO NETO, J. (Ed.). Fertilizantes: agroindústria \& sustentabilidade. Rio de Janeiro: Cetem, 2009. p.385-395.

MOREIRA, A.; CASTRO, C. de; OLIVEIRA, F.A. de; SALINET, L.H.; SFREDO, G.J. Efeito residual de rochas brasileiras como fertilizantes e corretivos da acidez do solo. Espaço \& Geografia, v.9, p.163-177, 2006.

PONTING, J.D.; JOSLYNG, M.A. Ascorbic acid oxidation and browning in apple tissue extracts. Archives of Biochemistry, v.19, p.47-63, 1948.

POZZA, A.A.A.; CURI, N.; COSTA, E.T. de S.; GUILHERME, L.R.G.; MARQUES, J.J.G. de S.M.; MOTTA, P.E.F. da. Retenção e dessorção competitivas de ânions inorgânicos em gibbsita natural de solo. Pesquisa Agropecuária Brasileira, v.42, p.16271633, 2007. DOI: 10.1590 / S0100-204X2007001100015.

PRATES, F.B. de S.; LUCAS, C. dos S.G.; SAMPAIO, R.A.; BRANDÃO JÚNIOR, D. da S.; FERNANDES, L.A.; JUNIO, G.R.Z. Crescimento de mudas de pinhão-manso em resposta a adubação com superfosfato simples e pó-de-rocha. Revista Ciência Agronômica, v.43, p.207-213, 2012. DOI: 10.1590/ S1806-66902012000200001.

PRATES, F.B. de S.; VELOSO, H.S.; SAMPAIO, R.A.; ZUBA JUNIOR, G.R.; LOPES, P.S.N.; FERNANDES, L.A.; MAIO, M.M. Crescimento de mudas de maracujázeiro-amarelo em resposta à adubação com superfosfato simples e pó de rocha. Revista Ceres, v.57, p.239-246, 2015. DOI: 10.1590/S0034737X2010000200016.

PULZ, A.L.; CRUSCIOL, C.A.C.; LEMOS, L.B.; SORATTO, R.P. Influência de silicato e calcário na nutrição, produtividade e qualidade da batata sob deficiência hídrica. Revista Brasileira de Ciência do Solo, v.32, p.1651-1659, 2008. DOI: 10.1590/S010006832008000400030 .

SANDIM, A. da S.; BÜLL, L.T.; FURIM, A.R.; LIMA, G. da S.; GARCIA, J.L.N. Phosphorus availability in oxidic soils treated with lime and silicate applications. Revista Brasileira de Ciência do Solo, v.38, p.1215-1222, 2014. DOI: 10.1590/S010006832014000400018.

SANTOS, H.G. dos; JACOMINE, P.K.T.; ANJOS, L.H.C. dos; OLIVEIRA, V.A. de; LUMBRERAS, J.F.; COELHO, M.R.; ALMEIDA, J.A. de; CUNHA, T.J.F.; OLIVEIRA, J.B. de. Sistema brasileiro de classificação de solos. 3.ed. rev. e ampl. Brasília: Embrapa, 2013. 353p.

SANTOS, W.O.; MATTIEllO, E.M.; COSTA, L.M. da; ABRAHÃO, W.A.P. Characterization of verdete rock as a potential source of potassium. Revista Ceres, v.62, p.392-400, 2015. DOI: 10.1590/0034-737X201562040009.

SARTO, M.V.M.; RAMPIM, L.; LANA, M. do C.; ROSSET, J.S.; ECCO, M.; WOBETO, J.R. Atributos químicos do solo e desenvolvimento da cultura do trigo em função da adubação silicatada. Revista Agrarian, v.7, p.390-400, 2014.

SILVA, A.A.S.; MEDEIROS, M.E.; SAMPAIO, J.A.; GARRIDO, F.M.S. Verdete de Cedro do Abaeté como fonte de potássio: caracterização, tratamento térmico e reação com $\mathrm{CaO}$. Revista Matéria, v.17, p.1061-1073, 2012. 
SILVA, E. de B.; NOGUEIRA, F.D.; GUIMARÃES, P.T.G. Qualidade de grãos de café beneficiados em resposta à adubação potássica. Scientia Agricola, v.59, p.173-179, 2002. DOI: 10.1590/ S0103-90162002000100025.

SILVA, E.A. da; CASSIOLATO, A.M.R.; MALTONI, K.L.; SCABORA, M.H. Efeitos da rochagem e de resíduos orgânicos sobre aspectos químicos e microbiológicos de um subsolo exposto e sobre o crescimento de Astronium fraxinifolium Schott. Revista Árvore, v.32, p.323-333, 2008. DOI: 10.1590/S010067622008000200015 .

SILVA, E.M. da; MALVINO, S.S.A.B. Análise climática do município de Patrocínio (MG). Caminhos da Geografia, v.10, p.93-108, 2005.

SILVA, F.C. da (Ed.). Manual de análises químicas de solos, plantas e fertilizantes. 2.ed. rev. e ampl. . Brasília: Embrapa Informação Tecnológica, 2009. 627p.
SILVEROL, A.C.; MACHADO FILHO, L. Utilização de pó de granito e manto de alteração de piroxenito para fertilização de solos. Revista Brasileira de Agroecologia, v.2, p.703-707, 2007.

SUMÁRIO MINERAL 2014. Brasília: DNPM, v.34, 2014. 141p.

THEODORO, S.H.; LEONARDOS, O.H. The use of rocks to improve family agriculture in Brazil. Anais da Academia Brasileira de Ciências, v.78, p.721-730, 2006. DOI: 10.1590/ S0001-37652006000400008.

TOLEDO PIZA, P.d'A. de; BERTOLINO, L.C.; SILVA, A. de A.S. da; SAMPAIO, J.A.; LUZ, A.B. da. Verdete da região de Cedro de Abaeté (MG) como fonte alternativa para potássio. Geociências, v.30, p.345-356, 2011.

VON WILPERT, K.; LUKES, M. Ecochemical effects of phonolite rock powder, dolomite and potassium sulfate in a spruce stand on an acidified glacial loam. Nutrient Cycling in Agroecosystems, v.65, p.115-127, 2003. DOI: 10.1023/A:1022103325310.

Received on May 31, 2017 and accepted on July 31, 2018 